\title{
RECHTSREGEL
}

Jurnal Ilmu Hukum Vol 2, No. 2 Desember 2019

P-ISSN 2622-6235, E-ISSN 2622-6243

rjih_fh@unpam.ac.id

\section{PENEGAKAN HUKUM TERHADAP PELAKU SEKALIGUS KORBAN PENYALAHGUNAAN NARKOTIKA DALAM UNDANG UNDANG NOMOR 35 TAHUN 2009 TENTANG NARKOTIKA}

\author{
Fahrizal Haris Harahap
}

Fakultas Hukum, Universitas Pamulang

Email: fahrizallawyer@gmail.com

Received: 16 Sept 2019 / Revised: 18 Okt 2019/Accepted: 15 Nov 2019

\begin{abstract}
ABSTRAK
Tujuan dari penelitian ini adalah untuk mengetahui dan menganalisa bagaimanakah pertimbangan Hakim dalam menerapkan terbuktinya unsur-unsur tindak pidana dan bagaimanakah pertimbangan Hakim dalam menjatuhkan pidana terhadap pelaku tindak pidana pelaku penyalahguna narkotika sebagaimana yang dihubungkan dengan SEMA No. 4 Tahun 2010 tentang Penempatan Penyalahgunaan, Korban Penyalahgunaan dan Pecandu Narkotika ke dalam lembaga rehabilitasi medis dan sosial. Sifat dalam penelitian hukum normatif ini adalah bersifat deskriptif yang bertujuan untuk menggambarkan secara lengkap dan sistematif mengenai masalah yang sedang diteliti terkait hak-hak yang dimiliki Terdakwa sehubungan dengan hak mendapatkan rehabilitasi medis dan sosial berdasarkan ketentuan hukum yang telah diatur dalam Pasal 4 UU No. 35 Tahun 2009 tentang Narkotika yang menyebutkan, "menjamin pengaturan upaya rehabilitasi medis dan rehabilitasi sosial bagi penyalah guna dan pecandu narkotika". Pengaturan tindak pidana penyalahgunaan narkotika berdasarkan Pasal 112 ayat (1) UU No. 35 Tahun 2009 tentang Narkotika. Seorang yang melakukan tindak pidana baru boleh di hukum apabilasi pelaku di anggap sanggup mempertanggung jawabkan perbuatannya.
\end{abstract}

Kata kunci:Narkotika,unsur-unsur pidana,hak rehablitasi

\section{ABSTRACT}

The purpose of this study is to find out and analyze how the Judges 'considerations in applying the proven elements of criminal acts and how the Judges' considerations in imposing a criminal act against narcotic offenders as connected with SEMA No. 4 of 2010 concerning the Placement of Abuse, Abuse Victims and Narcotics Addicts into medical and social rehabilitation institutions. The nature of this normative legal research is descriptive in nature which aims to 
describe in a complete and systematic way the problem being investigated in relation to the rights of the Defendant in connection with the right to medical and social rehabilitation based on the legal provisions stipulated in Article 4 of Law No. 35 of 2009 concerning Narcotics which states, "guaranteeing arrangements for medical rehabilitation and social rehabilitation for abusers and drug addicts". The regulation of criminal acts of narcotics abuse based on Article 112 paragraph (1) of Law no. 35 of 2009 concerning Narcotics. A person who commits a new crime may be judged to be the perpetrator of the offense deemed capable of taking responsibility for his actions.

\section{Keywords: Narcotics, criminal elements, rehabilitation right}

\section{PENDAHULUAN}

Narkotika merupakan obat atau bahan yang bermanfaat di bidang pengobatan, pelayanan kesehatan dan pengembangan ilmu pengetahuan. Namun, di sisi lain dapat menimbulkan ketergantungan yang sangat merugikan apabila dipergunakan tanpa adanya pengendalian, pengawasan yang ketat dan seksama. Narkotika ibarat pedang bermata dua, di satu sisi sangat dibutuhkan dalam dunia medis dan ilmu pengetahuan akan tetapi dilain sisi penyelahgunaannya sangat membahayakan masa depan generasi muda, ketentraman masyarakat dan mengancam eksistensi ketahanan nasional suatu bangsa, sehingga dibutuhkan aturan hukum yang mengatur agar dapat menekan jumlah penyalahgunaan dan peredaran narkotika secara ilegal, khususnya di Indonesia.

Sejalan semakin meningkatnya penyalahgunaan narkoba, pemerintah telah mengupayakan untuk menindak tegas para sindikat dan pengedar dengan memberikan hukuman berat, bahkan sampai hukuman mati. Adapun bagi korban pengguna atau pecandu, pemerintah telah mengupaya kan untuk mengurangi dampak buruk akibat penggunaan narkoba yaitu dengan cara memberikan fasilitas rehabilitasi, baik secara medis maupun sosial. Hal ini dilakukan agar korban pengguna narkoba dapat kembali sembuh, menjadi manusia 
produktif, mampu bekerja memenuhi kebutuhan kehidupan serta keluarganya dan menjadi generasi bangsa yang sehat dan kuat.

Namun kebijakan untuk menempatkan korban pengguna narkoba di tempat rehabilitasi tidak dapat berjalan dengan baik karena masih terbentur dengan ketentuan Undang-Undang Narkotika yang dalam hal ini, korban pengguna narkoba sampai sekarang ini masih harus diposisikan sebagai pelaku tindak pidana, akibatnya mereka tidak memperoleh perawatan dan pemulihan secara maksimal karena harus mendekam di dalam penjara.

Penegakan hukum mempunyai sasaran agar orang taat kepada hukum. Ketaatan masyarakat terhadap hokum disebabkan tiga hal, yakni: (1) takut berbuat dosa; (2) takut karena kekuasaan dari pihak penguasa berkaitan dengan hukum yang bersifat imperatif; dan (3) takut karena malu berbuat jahat. Penegakan hokum dengan sarana non penal mempunyai sasaran dan tujuan untuk kepentingan internalisasi. ${ }^{1}$

Dalam perkembangannya Mahkamah Agung ("MA") telah mengeluarkan Surat Edaran Mahkamah Agung ("SEMA") Nomor 4 Tahun 2010 tentang Penempatan Penyalahgunaan, Korban Penyalahgunaan dan Pecandu Narkotika kedalam Lembaga rehabilitasi medis dan sosial yang menjadi pegangan Hakim Pengadilan Negeri dan Pengadilan Tinggi dalam memutus Perkara. Selainitu, pada tahun 2011 lahir Peraturan Pemerintah Nomor 25 Tahun 2011 tentang Pelaksanaan Wajib Lapor Pecandu Narkotika, memberikan jaminan kepada pecandu dan/atau perawatan melalui medis dan rehabilitasi sosial. Kedua peraturan tersebut merupakan langkah maju dalam membangun paradigma penghentian kriminalisasi atau dekriminalisasi terhadap pecandu narkoba.

1 Siswantoro Sonarso, Penegakan Hukum Dalam Kajian Sosiologis, Raja Grafindo Persada, Jakarta, 2004, hal 142. 
Penerapan hukuman pidana (penjara) bagi korban pengguna narkoba di Indonesia terbukti tidak dapat menurunkan jumlah penyalahguna, bahkan setiap tahunnya mengalami peningkatan.

\section{PERMASALAHAN}

1. Bagaimanakah pertimbangan Hakim dalam menerapkan terbuktinya unsur-unsur tindak pidana penyalahgunaan narkotika menurut Pasal 112 ayat (1) Undang-Undang Nomor 35 Tahun 2009 tentang Narkotika dihubungkan dengan Surat Edaran Mahkamah Agung ("SEMA") Nomor 4 Tahun 2010 tentang Penempatan Penyalahgunaan, Korban Penyalahgunaan dan Pecandu Narkotika ke dalam lembaga rehabilitasi medis dan sosial pada putusan Pengadilan Negeri Jakarta Selatan Nomor: 1186/ Pid.Sus/ 2018/ PN.Jkt.Sel?

2. Bagaimanakah pertimbangan Hakim dalam menjatuhkan sanksi pidana penjara terhadap pelaku penyalahgunaan narkotika menurut Pasal 112 ayat (1) Undang-Undang Nomor 35 Tahun 2009 tentang Narkotika dihubungkan dengan Surat Edaran Mahkamah Agung ("SEMA") Nomor 4 Tahun 2010 tentang Penempatan Penyalahgunaan, Korban Penyalahgunaan dan Pecandu Narkotika ke dalam lembaga rehabilitasi medis dan sosial pada putusan Pengadilan Negeri Jakarta Selatan Nomor: 1186/ Pid.Sus/ 2018/ PN.Jkt.Sel?

\section{METODE PENELITIAN}

\section{Jenis Penelitian}

Penelitian ini adalah penelitian deskriptif analistis yang tujuannya untuk menyajikan gambaran lengkap mengenai eksplorasi dan klarifikasi mengenai fenomena atau kenyataan sosial, dengan jalan menjurnalkan sejumlah variabel yang 
berkenaan dengan masalah dan unit yang diteliti antara fenomena yang diuji menggunakan tipe penelitian normatif. Dengan menggunakan metode penelitian ini, Penulis akan memberikan gambaran lengkap mengenai tindak pidana penyalahgunaan narkotika dalam Putusan Pengadilan Nomor: 1186/ Pid.Sus/2018/ PN.Jkt.Sel.

2. Pendekatan Penelitian

Metode yang digunakan dalam penelitian ini yaitu pendekatan perundang-undangan, pendekatan Yurisprudensi atau keputusankeputusan Hakim terdahulu untuk menghadapi suatu perkara yang tidak diatur di dalam undang-undang dan azaz-azaz hokum lainnya. Metode ini mengkaji Putusan Perkara Pengadilan Negeri Nomor: 1186/Pid.Sus/2018/PN.Jkt.Sel dengan menerapkan UndangUndang Nomor 35 Tahun 2009 tentang Narkotika.

3. Bahan Penelitian

Bahan penelitian yang dipergunakan dalam penelitian ini, yaitu :

a. Bahan Hukum Primer, yaitu bahan hukum yang diperoleh dari pengaturan perundang-undangan, dalam hal ini UU Narkotika dan KUHP yang ada kaitannya dengan materi yang dibahas.

b. Bahan Hukum Sekunder, yaitu bahan hukum yang bersifat menjelaskan bahan hukum primer yang diperoleh dari literatur yang mempunyai sangkut paut dengan hokum pidana, tulisantulisan ilmiah, bahan-bahan kuliah, dokumen-dokumen serta perundang-undangan yang berlaku, yang erat hubungannya dengan narkotika.

c. Bahan Hukum Tersier atau Bahan Hukum Penunjang, mencakup 
1) Bahan-bahan yang memberi petunjuk-petunjuk maupun penjelasan terhadap hukum primer dan hukum sekunder. Misalnya :Kamus, Ensiklopedia dan lain sebagainya.

2) Bahan-bahan primer, sekunder dan tersier atau penunjang diluar bidang hukum yang dipergunakan untuk melengkapi dan menunjang data penelitian. Misalnya :Filsafat, Ekologi, Tehnik dan lain sebagainya.

\section{PEMBAHASAN}

\section{Kasus Posisi}

Pengadilan Negeri Jakarta Selatan, yang mengadili perkara pidana dengan acara pemeriksaan biasa dalam tingkat pertama, menjatuhkan putusan sebagai berikut dalam perkara tindak pidana penyalahgunaan narkotika terhadap Terdakwa yang bernama Ahmad Triadi, tempat lahir Jakarta, umur 28 Tahun, tanggal lahir 06 Juni 1989, jenis kelamin laki-laki, kebangsaan Indonesia, tempat tinggal di Jalan Dwi Warna II Gg. II No. 24, RT.014 / Rw.010, Kelurahan Karang Anyar, Kecamatan Sawah Besar, Jakarta Pusat, agama Islam, pekerjaan swasta dan Pendidikan terakhir Sekolah Dasar (SD).

Dalam kasus ini berawal pada hari Selasa tanggal 14 Agustus 2018 sekitar jam 19.30 wib, Terdakwa Ahmad Triadi pergi menemui sdr. Rael (DPO) di depan sekolah SD Cupnam Jalan Mangga Besar, Kelurahan Karang Anyar, Kecamatan Sawah Besar, Jakarta Pusat dengan maksud membeli narkoitka jenis shabu sehargaRp. 700.000,(tujuh ratus ribu Rupiah), setelah bertemu selanjutnya Terdakwa langsung menyerahkan uang pembelian kepada sdr. Rael (DPO) sedangkan sdr. Rael (DPO) menyerahkan 1 (satu) bungkus plastic bening berisikan narkotika jenis shabu kepada Terdakwa lalu Terdakwa membagi narkotika jenis shabu tersebut menjadi 2 (dua) paket narkotika jenis shabu yang selanjutnya 1 (satu) paket narkotika 
jenis shabu Terdakwa simpan di kantong celana belakang sebelah kanan dan yang 1 (satu) paket narkotika jenis shabu Terdakwa genggam dengan tangan kanan Terdakwa. Selanjutnya sekitar jam sekitar 20.00 wib Terdakwa pergi menuju took Indomaret yang beralamat di Jalan Dwi Warna, Kelurahan Karang Anyar, Kecamatan Sawah Besar, Jakarta Pusat yang sebelumnya janjian dengan sdr. Doni (DPO), lalu setelah sampai di depan toko Indomaret tiba-tiba Terdakwa ditangkap oleh beberapa orang anggota Polisi dari Satuan Narkoba Polsek Setiabudi Jakarta Selatan yaitu saksi Mujianto, SH, saksi M. Ali Kurniawan dan saksi Didik Setiawan yang sebelumnya mendapat informasi dari warga masyarakat bahwa di Jalan Dwi Warna, Kelurahan Karang Anyar, Kecamatan Sawah Besar Jakarta Pusat tersebut sering dijadikan tempat peredaran narkotika jenis shabu dan setelah dilakukan penggeledahan di temukan 1 (satu) paket narkotika jenis shabu yang sebelumnya Terdakwa simpan di kantong celana belakang sebelah kanan yang saat itu Terdakwa kenakan. Selanjutnya Terdakwa beserta bukti langsung diamankan kePolsek Setiabudi Jakarta Selatan untuk pemeriksaan lebih lanjut.

Pada Putusan Perkara No. 1186/Pid.Sus/2018/PN.Jkt.Sel, surat dakwaan Terdakwa dari Penuntut Umum dengan dakwaan yang disusun secara Subsidaritas. Dan segala sesuatu yang telah terjadi di persidangan sebagaimana termuat dalam Berita Acara Persidangan, maka dianggap sebagai satu kesatuan yang tidak terpisahkan dari putusan No. 1186/Pid.Sus/2018/PN.Jkt. Sel.

Dalam dakwaan, para Terdakwa didakwa oleh Jaksa Penuntut Umum melanggar:

PRIMAIR: Pasal 114 ayat (1) Undang-Undang Republik Indonesia No. 35 Tahun 2009 tentang Narkotika

SUBSIDAIR: Pasal 112 ayat (1) Undang-Undang Republik Indonesia No. 35 Tahun 2009 tentang Narkotika. 
Penulis akan menjabarkan bunyi pasal yang disebutkan dalam dakwaan primair dan dakwaan subsidair sebagai berikut:

Pasal 114 ayat (1) UU No. 35 Tahun 2009 tentang Narkotika, yang berbunyi:

(1) Setiap orang yang tanpa hak atau melawan hokum menawarkan untuk dijual, menjual, membeli, menerima, menjadi perantara dalam jual beli, menukar, atau menyerahkan Narkotika Golongan I, dipidana dengan pidana penjara seumur hidup atau pidana penjara paling singkat 5 (lima) tahun dan paling lama 20 (dua puluh) tahun dan dipidana denda paling sedikit Rp. 1.000.000.000,- (satu milyar Rupiah) dan paling banyak Rp. 10.000.000.000,(sepuluh milyar Rupiah).

Pasal 112 ayat (1) UU No. 35 Tahun 2009 tentang Narkotika, yang berbunyi:

(1) Setiap orang yang tanpa hak atau melawan hokum memiliki, menyimpan, menguasai, atau menyediakan pidana penjara paling singkat 4 (empat) tahun dan paling lama 12 (dua belas) tahun dan pidana denda paling sedikit Rp. 800.000.000,- (delapan ratus juta Rupiah) dan paling banyak Rp. 8.000.000.000,- (delapan milyar Rupiah).

Bahwa dari fakta-fakta di persidangan dari putusan yang Penulis analisis, maka Jaksa Penuntut Umum mempunyai keyakinan untuk mengajukan tuntutan dengan dakwaan, berdasarkan Tuntutan Jaksa Penuntut Umum yang telah diajukan dengan pada tanggal 05 Desember 2018 dengan Reg. Perkara Nomor : PDM684/JKTSL/Euh.2/10/2018 terhadap Terdakwa, yang pada pokoknya sebagai berikut :

1. Menyatakan Terdakwa Ahmad Triadi tidak terbukti bersalah melakukan tindak pidana "tanpa hak atau melawan hukum 
menawarkan untuk dijual, menjual, membeli, menerima, menjadi perantara dalam jual beli, menukar atau menyerahkan Narkotika Golongan I", oleh karena itu membebaskan Terdakwa dari dakwaan Primair;

2. Menyatakan Terdakwa Ahmad Triadi bersalah melakukan tindak pidana "tanpa hak atau melawan hukum memiliki, meyimpan, menguasai atau menyediakan Narkotika Golongan I bukan tanaman" sebagaimana diatur dalam dakwaan subsidair yaitu melanggar Pasal 112 ayat (1) UU RI No. 35 Tahun 2009 tentang Narkotika;

3. Menjatuhkan pidana terhadap Terdakwa Ahmad Tria didengan pidana penjara selama 5 (lima) tahun dikurangi selama Terdakwa berada dalam tahanan sementara dengan perintah Terdakwa tetap ditahan;

4. Menjatuhkan pidana denda terhadap Terdakwa sebesar Rp. 800.000.000,- (delapan ratus juta Rupiah), subsidair 3 (tiga) bulan penjara;

5. Menyatakan barang bukti berupa, 2 (dua) bungkus plastik bening masing-masing berisikan narkotika jenis shabu dengan berat netto seluruhnya 0,3996 gram (sisa hasil lab berat netto seluruhnya 0,3524 gram), dirampas untuk dimusnahkan;

6. Menyatakan supaya Terdakwa membayar biaya perkara sebesar Rp. 2.000,- (dua ribu Rupiah).

Berdasarkan tuntutan tersebut, Terdakwa melalui Penasehat Hukumnya mengajukan pembelaan secara tertulis tanggal 12 Desember 2018 yang pada pokoknya memohon kepada Majelis Hakim agar berkenan menjatuhkan hukuman yang seringan-ringannya terhadap Terdakwa, mengingat:

1. Terdakwa telah menyesali perbuatannya;

2. Terdakwa belum pernah dihukum sebelumnya; 
3. Terdakwa berlaku sopan selama dalam persidangan;

4. Terdakwa adalah tulang punggung bagi keluarga besarnya.

Bahwa terhadap pembelaan tersebut, Penuntut Umum tetap pada tuntutannya sehingga tidak ada Replik dari Penuntut Umum maupun Duplik dari Terdakwa.

Analisa Hakim dalam menerapkan unsur-unsur tindak pidana penyalahgunaan narkotika menurut Pasal 112 ayat (1) UU No. 35 Tahun 2009 tentang Narkotika pada Putusan Pengadilan Negeri Jakarta Selatan Nomor: 1186/Pid.Sus/2018/PN.Jkt.Sel

1. Dasar Pertimbangan Hakim

Pertimbangan Hakim merupakan salah satu aspek terpenting dalam menentukan terwujudnya nilai dari suatu putusan Hakim yang mengandung keadilan dan mengandung kepastian hukum, di samping itu juga mengandung manfaat bagi para pihak yang bersangkutan sehingga pertimbangan Hakim ini harus disikapi dengan teliti, baik, dan cermat. Pada putusan No. 1186/Pid.Sus/2018/Jkt.Sel yang dimana surat dakwaan di susun secara subsidaritas, maka Hakim hanya mempertimbangkan dakwaan subsidair dan tidak membacakan kembali dakwaan primair.

Putusan Hakim merupakan puncak klimaks dari suatu perkara yang sedang diperiksa dan diadili oleh seorang Hakim. Hakim memberikan keputusannya mengenai hal-hal sebagai berikut:2

a. Keputusan mengenai peristiwanya, apakah Terdakwa telah melakukan perbuatan yang dituduhkan kepadanya.

2Sudarto, Hukum dan Hukum Pidana, Alumni, Bandung, 1986, hal 74. 
b. Keputusan mengenai hukumnya, apakah perbuatan yang dilakukan Terdakwa itu merupakan suatu tindak pidana dan apakah Terdakwa bersalah dan dapat dipidana.

c. Keputusan mengenai pidananya, apakah Terdakwa memangdapat dipidana.

Pedoman pemberian pidana akan memudahkan Hakim dalam menetapkan pemidanaannya, setelah terbukti bahwa tertuduh telah melakukan perbuatan yang dituduhkan kepadanya. Dalam daftar tersebut dimuat hal-hal bersifat subyektif yang menyangkut hal-hal yang diluar pembuat. Dengan memperhatikan butir-butir tersebut diharapkan penjatuhan pidana lebih proporsional dan lebih dipahami mengapa pidananya seperti yang dijatuhkan itu. ${ }^{3}$

2. Analisa Penerapan Unsur-unsur

Terdakwa didakwa oleh Penuntut Umum dengan dakwaan yang disusun secara subsidaritas, maka Penulis akan menguraikan unsur yang Majelis Hakim pilih dan pertimbangkan dalam putusan tersebut yaitu Dakwaan Subsidair yakni melanggar Pasal 112 ayat (1) UU No. 35 Tahun 2009 tentang Narkotika, sebagai berikut:

1) Setiap Orang;

2) Tanpa Hak atau Melawan Hukum;

3) Memiliki, menyimpan, menguasai atau menyediakan Nakotika Golongan I dalam bentuk tanaman;

a. Pembuktian Unsur

Pembuktian dari penerapan unsur-unsur yang terkandung dalam Pasal 112 ayat (1) UU No. 35 Tahun 2009 tentang Narkotika, sebagai berikut:

1) Unsur Setiap Orang

${ }^{3}$ Muladi dan Barda Nawawi Arif, Teori-teori dan Kebijakan Pidana, Alumni, Bandung, 1998, hal 67. 
Yang dimaksud dengan unsur "setiap orang" dalam perkara ini memberikan petunjuk mengenai orang atau manusia sebagai subjek hukum yang memiliki hak dan kewajiban serta dapat dipertanggungjawabkan secara hukum;

Di dalam persidangan Terdakwa setelah diperiksa dan diteliti identitasnya oleh Majelis Hakim ternyata sama dengan identitas Terdakwa yang termuat dalam Surat Dakwaan Jaksa Penuntut Umum, dan di persidangan Terdakwa mampu menjawab seluruh pertanyan Majelis Hakim dan Jaksa Penuntut Umum denganb aik dan lancar, sehingga hal tersebut menunjukkan bahwa Terdakwa saat melakukan perbuatan maupuan pada saat memberikan keterangan dipersidangan berada dalam kondisi sehat jasmani dan rohani serta tidak ditemukan adanya alasan pembenar maupun alasan pemaaf, maka Terdakwa dianggap mampu bertanggung jawab atas keseluruhan perbuatan pidana yang telah dilakukannya;

2) Unsur Tanpa Hak atau Melawan Hukum

Yang dimaksud dengan unsur ini adalah bahwa perbuatan Terdakwa tersebut bertentangan dengan hukum dan kepatutan atau bertentangan dengan Undang-Undang No. 35 Tahun 2009 tentang Narkotika;

Sesuai fakta-fakta yang terungkap dipersidangan berupa keterangan saksi-saksi, keterangan Terdakwa dan dihubungkan dengan barang bukti dalam perkara ini yaitu Terdakwa tertangkap pada hari Selasa, tanggal 14 Agustus 2018 sekitar jam 20.00 wib, saat Terdakwa berada di depan toko indomaret yang beralamat di Jalan Dwi Warna, Kelurahan KarangAnyar, Kecamatan Sawah Besar, Jakarta Pusat dan setelah dilakukan penggeledahan ditemukan 1 
(satu) paket Narkotika Golongan I jenis shabu yang saat itu berada digenggaman tangan kiri Terdakwa dan 1 (satu) paket Narkotika Golongan I jenis shabu yang sebelumnya Terdakwa simpan di kantong celana belakang sebelah kanan yang saat itu Terdakwa kenakan, bahwa barang bukti Narkotika jenis shabu tersebut diakui oleh Terdakwa sebagai miliknya dan Terdakwa mendapatkan barang bukti tersebut dengan cara membeli dari Sdr. Rael (DPO) sehargaRp. 700.000,- (tujuh ratus ribu Rupiah).

3) Unsur memiliki, menyimpan, menguasai atau menyediakan Narkotika Golongan I bukan tanaman

Berdasarkan keterangan saksi-saksi, keterangan Terdakwa serta dikaitkan dengan barang bukti yang diajukan dimuka persidangan ternyata Terdakwa dalam memiliki, menyimpan, menguasai atau menyediakan Narkotika Golongan I dalam bentuk bukan tanaman tersebut bukan untuk tujuan pengobatan maupun tujuan ilmu pengetahuan dan Terdakwa memiliki, menyimpan, menguasai atau menyediakan Narkotika Golongan I dalam bentuk bukan tanaman sebanyak tersebut tidak memiliki ijin dari pihak yang berwenang dalam hal ini adalah Departemen Kesehatan republik Indonesia;

Berdasarkan Berita Acara Pemeriksaan Laboratoris dari Balai Laboratorium Narkoba BNN RI No. 408AT/ VIII/ 2018/ BALAI LAB NARKOBA, pada tanggal 29 Agustus 2018 dapat disimpulkan bahwa : 2 (dua) bungkus plastik bening masingmasing berisikan kristal warna putih dengan berat netto seluruhnya 0,3996 gram, yang disita dan diakui milik Terdakwa tersebuta dalah benar mengandung Metamfetamina dan terdaftar dalam Golongan I Nomor Urut 61 Lampiran 
Undang-Undang RI Nomor 35 Tahun 2009 tentang Narkotika, (sisahasil lab beratnettoseluruhnya 0,3524 gram). Dengan demikian Majelis Hakim berpendapat bahwa unsur ini telah terpenuhi;

Analisa Pertimbangan Hakim dalam menjatuhkan sanksi pidana penjara terhadap pelaku penyalahgunaan narkotika menurut Pasal 112 ayat (1) Undang-Undang Nomor 35 Tahun 2009 tentang Narkotika pada Putusan Pengadilan Negeri Jakarta Selatan Nomor: 1186/Pid.Sus/2018/PN.Jkt.Sel.

Pada putusan No. 1186/ Pid.Sus/ 2018/ PN.Jkt.Sel yang dihubungkan dengan Surat Edaran Mahkamah Agung ("SEMA") Nomor 4 Tahun 2010 tentang Penempatan Penyalahgunaan, Korban Penyalahgunaan dan Pecandu Narkotika kedalam lembaga rehabilitasi medis dan sosial.

Dalam menjatuhkan pidana terhadap suatu kasus harus sesuai dengan peraturan perundang-undangan, tidak boleh bertentangan dengan peraturan yang lainnya, dan tidak boleh memihak. Hakim mengkongkretkan sanksi pidana yang terdapat dalam suatu peraturan dengan menjatuhkan pidana Terdakwa dalam kasus tertentu. Hakim dalam menjatuhkan pidana terhadap suatu kasus sangatlah banyak hal-hal yang mempengaruhinya, yaitu yang bisa dipakai sebagai bahan pertimbangan untuk menjatuhkan putusan pemidanaan sesuai dengan peraturan perundang-undangan yang berlaku. Hakim berbeda dengan pejabat-pejabat lain, ia harus benarbenar menguasai hukum sesuai dengan sistem yang dianut di Indonesia dalam pemeriksaan di sidang pengadilan. 
Surat Edaran Mahkamah Agung ("SEMA") Nomor 4 Tahun 2010 tentang Penempatan Penyalahgunaan, Korban Penyalahgunaan dan Pecandu Narkotika kedalam Lembaga rehabilitasi medis dan social dihubungkan dengan putusan Pengadilan Negeri Jakarta Selatan Nomor: 1186/ Pid.Sus/ 2018/ PN.Jkt.Sel

Dalam UU No. 35 Tahun 2009 tentang Narkotika ketentuan hukum yang mengatur mengenai rehabilitasi terhada ppenyalah guna atau pecandu narkotika diatur dalamPasal 54, 56, 103 dan dikaitkan dengan Pasal 127 UU No. 35 Tahun 2009 tentang Narkotika. Hal yang menarik dalam UU No. 35 Tahun 2009 tentang Narkotika terdapat dalam Pasal 103, dimana kewenangan Hakim untuk menjatuhkan vonis/sanksi bagi seseorang yang terbukti sebagai pecandu narkotika dapat melakukan 2 (dua) hal. Pertama, Hakim dapat memutuskan untuk memerintahkan yang bersangkutan menjalani pengobatan dan/atau perawatan apabila pecandu narkotika tersebut terbukti bersalah melakukan tindak pidana narkotika. Kedua, Hakim dapat menetapkan untuk memerintahkan yang bersangkutan menjalani pengobatan dan/atau perawatan, apabila pecandu narkotika tersebut tidak terbukti bersalah melakukan tindak pidana narkotika. Secara tersirat kewenangan ini, mengakui bahwa pecandu narkotika, selain sebagai pelaku tindak pidana juga sekaligus korban dari kejahatan itu sendiri yang dalam sudut viktimologi kerap disebut dengan Self Victimization atau Victimless Crime.

Dengan memperhatikan sebagian besar narapidana atau tahanan kasus narkotika adalah masuk kategori pemakai atau bahkan sebagai korban yang jika dilihat dari aspek kesehatan mereka sesungguhnya orang-orang yang menderita sakit, oleh karena itu memenjarakan yang bersangkutan bukanlah langkah yang tepat, maka Mahkamah Agung dengan tolak ukur Pasal 104 UU No. 35 
Tahun 2009 tentang Narkotika ,mengambil langkah majudi dalam membangun paradigma penghentian kriminalisasi atau diskriminalisasi terhadap pecandu narkotika dengan mengeluarkan Surat Edaran Mahkamah Agung No. 4 Tahun 2010 tentang Penetapan Penyalahguna dan Pecandu Narkotika kedalam Lembaga Rrehabilitasi Medis dan Rehabilitasi Sosial. Dimana SEMA ini dapat dipergunakan sebagai dasar pertimbangan atau acuan Hakim dalam menjatuhkan sanksi rehabilitasi.

Pada putusan Pengadilan Negeri Jakarta Selatan Nomor : 1186/Pid.Sus/2018/PN.Jkt.Sel, Terdakwa Ahmad Tria ditidak pernah menjalani proses asesmen dan berdasarkan barang bukti yang dihadirkan dalam persidangan kurang dari 1 (satu) gram atau total berat seluruhnya hanya 0,3996 gram, maka menurut Penulis seharusnya Terdakwa tidak dijatuhi pidana penjara melainkan rehabilitasi baik medis atau sosial.

\section{KESIMPULAN}

1. Pertimbangan Hakim dalam menerapkan terbuktinya unsur-unsur tindak pidana pada putusan Pengadilan Negeri Jakarta Selatan Nomor: 1186/Pid.Sus/2018/PN.Jkt.Sel dilakukan dengan cara membuktikan setiap unsur dari Pasal 112 ayat (1) Undang-Undang No. 35 Tahun 2009 tentang Narkotika dengan alat bukti sebagaimana diatur dalam Pasal 184 KUHAP, Penulis setuju dengan pertimbangan Majelis Hakim dalam menerapkan unsurunsur tindak pidana penyalahgunaan narkotika terhadap Terdakwa telah terpenuhi berdasarkan Berita Acara Pemeriksaan Laboratoris dari Balai Laboratorium Narkoba BNN RI No. 408AT/ VIII /2018 BALAI LAB NARKOBA, pada tanggal 29 Agustus 2018. bahwa barang bukti berupa 2 (bungkus) plastik bening masing-masing berisikan kristal warna putih yang disita dan diakui milik 
Terdakwa adalah benar mengandung Metamfetamina dan terdaftar dalam Golongan I No. Urut 61 Lampiran UU RI No. 35 Tahun 2009 tentang Narkotika.

2. Pertimbangan Hakim dalam menjatuhkan pidana terhadap putusan Pengadilan Negeri Jakarta Selatan Nomor 1186/ Pid.Sus/ 2018/ PN.Jkt.Sel. Menurut Penulis, Majelis Hakim dalam menjatuhkan pidana terhadap Terdakwa tindak pidana penyelahgunaan narkotika jika dikaitkan dengan SEMA No. 4 Tahun 2010 tentang Penetapan Penyalahguna, Korban Penyalahguna dan Pecandu Narkotika kedalam Lembaga Rehabilitasi Medis dan Sosial belum tepat, dimana SEMA ini dapat dipergunakan sebagai dasar pertimbangan atau acuan Hakim dalam menjatuhkan sanksi rehabilitasi.

\section{SARAN}

1. Dalam melakukan upaya penanggulangan dan pencegahan agar tindak pidana penyalahgunaan narkotika ini harus terus meningkat yakni dengan apparat penegak hukum bersama-sama apparat pemerintah melakukan pengawasan dalam peredaran narkotika yang ada di Indonesia dan mengevaluasi kembali undang-undang yang mengatur ketentuan di dalam UndangUndang Narkotika, hal ini dikarenakan banyaknya penyalahgunaan Narkotika secara berkesinambungan dan demi terjaminnya generasi muda yang berkualitas tanpa narkotika.

2. Hakim sebagai seorang yang memeriksa dan mengadili lebih menelaah terhadap hal tersebut. Hal-hal yang menjadi hak tersangka atau Terdakwa agar mewujudkan suatu proses hukum yang adil. Bahwa Hakim adalah seorang yang memeriksa dan mengadili dalam memutus suatu perkara tidak boleh bertentangan dengan perundang-undangan lainnya. 


\section{DAFTAR PUSTAKA}

\section{Buku}

Achmad Ali, 2002, MenguakTabirHukum (Suatu Kajian Filosofis dan Sosiologis), Jakarta: Gunung Agung.

Adami Chazawi, 2005, Kemahiran Dan Keterampilan Praktik Hukum Pidana, Malang: Bayumedia.

Agus Rusianto, 2016, Tindak Pidana \& Pertanggungjawaban Pidana Tinjauan Kritis Melalui Konsistensi Antara Asas, Teori, dan Penerapannya, Jakarta: Fajar Interpratama Mandiri.

Ali Yafie, Ahmad Sukarja, dkk, 2008, Ensiklopedi Hukum Pidana Islam, Edisi Indonesia, Jakarta: Kharisma Ilmu.

Andi Hamzah, 2005, Azas - Azas Hukum Pidana, Jakarta: Yarsif Watampone.

Andi Hamzah, 1993, PelaksanaanPeradilanPidanaBerdasarkanTeori dan Praktek, Jakarta: Rineka Cipta.

Azhary, 1994, Negara Hukum Indonesia, Jakarta: Universitas Indonesia.

Bambang Poernomo, 1994, Asas - Asas Hukum Pidana, Jakarta: Ghalia Indonesia.

Barda Nawawi Arief, 2001, Masalah Penegakan Hukum dan Kebijakan Penanggulangan Kejahatan, Bandung: PT. Citra Aditya Bakti.

Chairul Huda, 2006, Dari Tiada Pidana Tanpa Kesalahan Menuju Kepada Pertanggungjawaban Pidana Tanpa Kesalahan, Jakarta: Kencana Prenada Media Group, Cet. I.

E. Utrecht, 1994, Rangkaian Sari Kuliah Hukum Pidana I, Surabaya: Pustaka Tinta Mas.

E.Y. Kanter dan S.R. Sianturi, 2002, Asas-Asas Hukum Pidana di Indonesia dan Penerapannya, Jakarta: Storia Grafika.

Gatot Supramono, 2001, Hukum Narkoba Indonesia, Jakarta: Djambatan. 
Fahrizal Haris Harahap

Hadari dan Nawawi, 2007, Metode Penelitian Barang Sosial, Yogyakarta: Universitas Gajah Mada Press.

Hari Sasangka, 2003, Narkotika dan Psikotropika Dalam Hukum Pidana, Bandung: Mandar Maju.

Kusno Adi, 2009, Diversi Sebagai Upaya Alternatif Penanggulangan Tindak Pidana Narkotika Oleh Anak, Malang: UMM Press.

Lilik Mulyadi, 2007, Kekuasaan KeHakiman, Surabaya: Bina Ilmu.

Mahmud Mulyadi dan Feni Antoni Surbakti, 2010, Politik Hukum Pidana Terhadap Kejahatan Korporasi, Jakarta: PT Softmedia.

Mardani, 2008, Penyalahgunaan Narkotika Dalam Perspektif Hukum Islam dan Hukum Pidana Nasional, Jakarta: Raja Grafindo Persada.

Martiman Prodjohamidjojo, 1997, Memahami Dasar-Dasar Hukum Pidana Indoensia 2, Jakarta: PT Pradyna Paramita, Cetakan Pertama.

Moeljatno, 2002, Asas - Asas Hukum Pidana, Jakarta: Rineka Cipta.

Mukti Fajar MD dan Yulianto Achmad, 2010, Dualisme Penelitian Hukum Normatif dan Hukum Empiris, Yogyakarta: Pustaka Pelajar.

Muladi dan Barda Nawawi Arif, 1998, Teori-teori dan Kebijakan Pidana, Bandung: Alumni.

Muladi dan Dwidja Priyatno, 2010, Pertanggungjawaban Pidana Korporasi, Jakarta: Kencana Prenada Group, Cet. I.

Mulyana W Kusuma, 1988, kejahatan dan Penyimpangan, Jakarta: Yayasan LBH Jakarta.

O.C. Kaligis \&Associates, 2002, Narkoba dan Peradilannya di Indonesia, Reformasi Hukum Pidana Melalui Perundangan dan Peradilan, Bandung: Alumni.

P.A.F Lamintang, 1997, Dasar-Dasar Hukum Pidana Indonesia, Bandung: PT Citra Aditya Bakti.

Peter Mahmud Marzuki, 2008, Pengantar Ilmu Hukum, Jakarta: Kencana. 
Prapto Soepardi, 1991, Surat Dakwaan, Surabaya: Usaha Nasional.

Rachman Hermawan, 2005, Penyalahgunaan Narkotika Oleh Para Remaja, Bandung: Eresco.

Ridwan Syahrani, 1999, Rangkuman Intisari Ilmu Hukum, Bandung: Citra Aditya Bakti.

Roeslan Saleh, 1983, Perbuatan Pidana dan Pertanggungjawban Pidana Dua Pengertian Dasar Dalam Hukum Pidana, Jakarta: Aksara Baru,.

Siswantoro Sonarso, 2004, Penegakan Hukum Dalam Kajian Sosiologis, Jakarta: Raja Grafindo Persada.

Soedarto, 1981, Kapita Selekta Hukum Pidana, Bandung: Alumni.

Sofjan Sastrawidjaja, 2003, Hukum Pidana, Asas Hukum Pidana Sampai Dengan Alasan Peniadaan Pidana, Bandung: Armico.

Sudarto, 1986, Hukum dan Hukum Pidana, Bandung: Alumni.

Sudarto, 1990, Hukum Pidana I, Semarang: Yayasan Sudarto, Cet ke2.

Sudarto, 2007, Hukum Pidana, Jakarta: PT Sinar Grafika.

Teguh Prasetyo, 2011, Hukum Pidana, Jakarta: Rajawali Pers.

Theo Hujibers, 2010, Filsafat Hukum, Yogyakarta: Kanisius, Cetakan ke 15.

Wirjono Prodjodikoro, 2009, Asas - Asas Hukum Pidana di Indonesia, Bandung: Refika Aditama. 